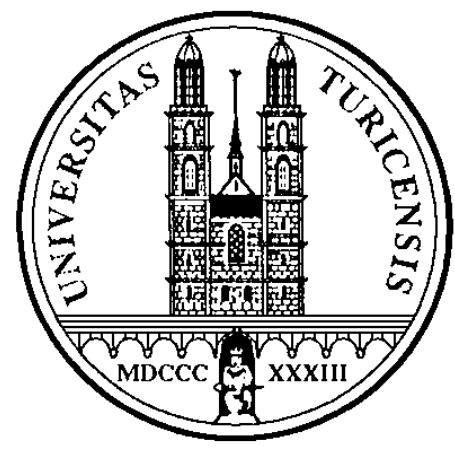

Institute for Empirical Research in Economics

University of Zurich

Working Paper Series

ISSN 1424-0459

Published in:

Journal of Institutional and Theoretical Economics, Vol. 155, 1999, 6664-695

Working Paper No. 5

Social Comparisons, Inequality, and Growth

Markus Knell

April 1999 


\title{
Social Comparisons, Inequality, and Growth
}

\author{
Markus Knell \\ Institute for Empirical Research in Economics \\ University of Zürich
}

Revised Version: July 1999

Keywords: Income inequality; Growth; Consumption externalities;

General field: Macroeconomics

JEL classification: E21; O40; D30

\footnotetext{
* I am grateful to Giuseppe Bertola, Michael Kosfeld, Arno Riedl, two anonymous referees and in particular to Simon Gächter and Josef Zweimüller for valuable comments and discussions.
} 


\begin{abstract}
Over the recent years one could repeatedly hear the claim that a rising concern for relative standing (in terms of consumption) was partly responsible for the decline in household savings and in growth that could be observed in some developed countries (particularly in the US) and that the rise in income inequality had further aggravated this process.

In this paper we want to analyze under which conditions (concerning the importance of social comparisons for peoples' behavior and their choice of reference groups) this claim is valid. We show that an increase in a societies' concern for relative standing aggravates a negative impact of inequality on growth if two conditions are fulfilled: individuals have a higher concern for their present than for their future relative standing and individuals have a tendency to find their reference groups among people that are wealthier then they are themselves.

Empirical data suggest that the negative impact of inequality on growth is stronger in highly developed economies. This is compatible with the explanation that is presented in this paper if individuals living in highly developed countries are more likely to have a high concern for relative standing. We will argue (using research on the cultural consequences of economic development) that this is a reasonable assumption to make.
\end{abstract}




\section{References}

AKERLOF, G. A. [1997], „Social Distance and Social Decisions“, Econometrica, 65(5), 10051027.

Alesina, A. AND D. RodRIK [1994], „Distributive Politics and Economic Growth“, Quarterly Journal of Economics, 109(2), 465-490.

BAgwell, L. S. AND D. B. BernheIM [1996], „Veblen Effects in a Theory of Conspicuous Consumption“, American Economic Review, 86(3), 349-373.

BAKSHI, G. S. AND Z. CHEN [1996], "The Spirit of Capitalism and Stock-Market Prices", American Economic Review, 86(1), 133-157.

BANERJEE, A. AND A. NEWMAN [1991], „Risk-Bearing and the Theory of Income Distribution“, Review of Economic Studies, 58(2), 211-235.

BÉNABOU, R. [1996], „Inequality and Growth“, pp. 11-74. in: B. S. Bernanke and J. Rotemberg (eds.), NBER Macroeconomics Annual, The MIT Press: Cambridge, MA.

BENHABIB, J. AND A. Rustichini [1996], „Social Conflict and Growth“, Journal of Economic Growth, 1(1), 125-142.

BERnHEIM, D. B. [1994], „A Theory of Conformity“, Journal of Political Economy, 102(5), 841-877.

Bertola, G. [1993], „Factor Shares and Savings in Endogenous Growth“, American Economic Review, 83(5), 1184-1198.

BosKIN, M. AND E. SHESHINSKI [1978], „Optimal Redistributive Taxation when Individual Welfare Depends on Relative Income“, Quarterly Journal of Economics, 92(4), 589-601.

Bowles, S. [1998], „Endogenous Preferences: The Cultural Consequences of Markets and Other Economic Institutions“, Journal of Economic Literature, 36(1), 75-111.

CARroll, C, J. Overland And D. Weil [1997], „Comparison Utility in a Growth Model“, Journal of Economic Growth, 2(4), 339-367.

Chung, J.-W. [1994], Utility and Production Functions: Theory and Applications, Blackwell: Oxford and Cambridge, MA.

Clark, A. E. AND A. J. Oswald [1996], ,Satisfaction and Comparison Income“, Journal of Public Economics, 61(3), 359-381.

Clark, A. E. AND A. J. Oswald [1998], „Comparison-Concave Utility and Following Behaviour in Social and Economic Settings“, Journal of Public Economics, 70(1), 133-155.

Cole, H. L., G. J. Mailath And A. Postlewaite [1992], „Social Norms, Savings Behavior, and Growth“, Journal of Political Economy 100(6), 1092-1125. 
CoRneO, G. AND O. JeAnne [1997], „Conspicuous Consumption, Snobbism and Conformism“, Journal of Public Economics, 66(1), 55-71.

CORNEO, G. AND O. JEANNE [1998], „Social Organization, Status, and Savings Behavior“, Journal of Public Economics, 70(1), 37-51.

DASGUPTA, P. [1997], „Economic Development and the Idea of Social Capital“, Unpublished Manuscript, University of Cambridge.

DEININGER, K. AND L. SQUIRE [1996], „A New Data Set Measuring Income Inequality“, World Bank Economic Review, 10(3), 565-591.

Di Tella, R., R. J. MacCulloch AND A. J. Oswald [1997], „The Macroeconomics of Happiness“, Working paper, Harvard Business School.

DIENER, E. [1984], „Subjective Well-Being“, Psychological Bulletin, 95(3), 542-575.

DUESENBERRY, J. S. [1949], Income, Saving and the Theory of Consumer Behavior, Harvard University Press: Cambridge, MA.

EASTERLIN, R. [1973], „Does Economic Growth Improve the Human Lot? Some Empirical Evidence“, pp. 89-125 in: P. David and M. Reder (eds.), Nations and Households in Economic Growth: Essays in Honor of Moses Abramovitz, Stanford University Press. Stanford, CA.

FEHR, E. AND K. M. SCHMIDT [1998], „A Theory of Fairness, Competition, and Cooperation“, Working Paper, University of Zurich.

Fershtman, C., K. M. MurPhy AND Y. WeISS [1996], ,Social Status, Education, and Growth“, Journal of Political Economy, 104(1), 108-132.

FrANK, R. H. [1984], ,Are Workers Paid Their Marginal Products?“, American Economic Review, 74(4), 549-571.

Frank, R. H. [1985a], Choosing the Right Pond. Human Behavior and the Quest for Status, Oxford University Press: New York and Oxford.

FRANK, R. H. [1985b], „The Demand for Unobservable and Other Nonpositional Goods“, American Economic Review, 75(1), 101-116.

FRANK, R. H. [1999], Luxury Fever. Why Money Fails to Satisfy in an Era of Excess, The Free Press: New York.

GALOR, O. AND J. ZEIRA [1993], „Income Distribution and Macroeconomics“, Review of Economic Studies, 60(1), 35-52.

Glaeser, E., J. ScheinKMAN AND A. SHLEIFER [1995], „Economic Growth in a CrossSection of Cities", NBER Working Paper 5013. 
GREIF, A. [1994], „Cultural Beliefs and the Organization of Society: A Historical and Theoretical Reflection on Collectivist and Individualist Societies“, Journal of Political Economy, 102(5), 912-950.

Hofstede, G. [1982], Culture’s Consequences, Sage Publications: Newbury Park.

Johansson-Stenman, O., F. CARLSSON AND D. DARUVAla [1999], "Measuring Hypothetical Grandparents' Preferences for Equality and Status”, Working paper, Göteborg University.

Kapteyn, A., S. van De Geer, H. van De Stadt And T. WAnsbeek [1997], "Interdependent Preferences: An Econometric Analysis", Journal of Applied Econometrics, 12, 665-686.

KNACK, S. AND P. KeEFER [1997], „Does Social Capital Have an Economic Payoff? A CrossCountry Investigation“, Quarterly Journal of Economics, 112(4), 1251-1288.

LAYARD, R. [1980], „Human Satisfaction and Public Policy“, Economic Journal, 90(363), 737-750.

LoEWEnstein, G. F., L. ThOMPSON AND M. H. BAZERMAN [1989], „Social Utility and Decision Making in Intertemporal Contexts“, Journal of Personality and Social Psychology, 57(3), 426-441.

Merton, R. AND A. KITT [1950], „Contributiuons to the Theory of Reference Group Behavior", in: R. Merton and P. Lazarsfeld (eds.), Continuities in Social Research: Studies in the Scope and Method of Reference Group Behavior, The Free Press: Glencoe, Ill.

Myers, D. G. AND E. DiENER [1996], „The Pursuit of Happiness“, Scientific American, May, 54-56.

OKun, A. M. [1975], Equality and Efficiency. The Big Tradeoff, The Brookings Institution.

PEROTTI, R. [1993], „Political Equilibrium, Income Distribution, and Growth“, Review of Economic Studies, 60(4), 755-776.

PEROTTI, R. [1996], „Growth, Income Distribution, and Democracy: What the Data Say“, Journal of Economic Growth, 1(2), 149-187.

Persson, T. AND G. TABELlini [1994], „Is Inequality Harmful for Growth?““, American Economic Review, 84(3), 600-621.

PSACHAROPOULOS, G. [1993], „Returns to Investment in Education: A Global Update“, World Development, 22(9), 1325-1343.

RABIN, M. [1998], „Psychology and Economics“, Journal of Economic Literature, 36(1), 11 46.

RAINWATER, L. [1974], What Money Buys, Basic Books: New York.

RoBerTI, P. [1980], „Counting the Poor: A Review of the Situation Existing in Six Industrialized Nations“, pp. 306-340 in: A. B. Atkinson (ed.), Wealth, Income and Inequality, Oxford University Press: New York. 
ROMER, P. M. [1986], „Increasing Returns and Long-run Growth“, Journal of Political Economy, 94(5), 1002-1037.

Ross, L. AND R. NisBetT [1991], The Person and the Situation, Temple University Press: Philadelphia.

Runciman, W. G. [1966], Relative Deprivation and Social Justice, University of California Press: Berkeley and Los Angeles.

SCHOR, J. [1998], The Overspent American. Upscaling, Downshifting, and the New Consumer, Basic Books: New York.

SEN, A. [1983], „Poor, Relatively Speaking“, Oxford Economic Papers, 35(2), 153-169.

SolnICK, S. AND D. HemENwAy [1998], „Is More Always Better? A Survey on Positional Concerns“, Journal of Economic Behavior and Organization, 37(3), 373-383.

Stone, R. J. [1954], „Linear Expenditure Systems and Demand Analysis: An Application to the Pattern of British Demand“, Economic Journal, 64, 511-527.

Thurow, L. C. [1996], The Future of Capitalism, Penguin Books: New York.

Tornell, A. AND A. Velasco [1992], „The Tragedy of the Commons and Economic Growth: Why Does Capital Flow from Poor to Rich Countries?“, Journal of Political Economy, 100(6), 1208-1231.

Townsend, P. [1980], „Research on Poverty“, pp. 298-305 in: A. B. Atkinson (ed.), Wealth, Income, and Inequality, Oxford University Press: New York.

TVERSKY, A. AND D. KAHNEMAN [1973], „Availability: A Heuristic for Judging Frequency and Probability“, Cognitive Psychology, 5(2), 207-232.

VAn DE StadT, H., A. KAPTEYN AND S. VAN DE GeER [1985], "The Relativity of Utility: Evidence from Panel Data", Review of Economics and Statistics, 67(2), 179-187.

WeISS, Y. AND C. FERSHTMAN [1998], „Social Status and Economic Performance: A Survey“, European Economic Review, 42(3-5), 801-20. 
Table 1

Impact of inequality on growth in high-income and low-income countries

\begin{tabular}{|l|ccc|}
\hline & \multicolumn{3}{c|}{ GR6085 } \\
\hline & $(1)$ & $(2)$ & $(3)$ \\
\hline & Largest poss. & High-Income & Low-Income \\
& sample & sample & sample \\
& $(\mathrm{N}=83)$ & $(\mathrm{N}=41)$ & $(\mathrm{N}=42)$ \\
Const. & 0.0159 & & 0.0102 \\
& $(1.54)$ & 0.0488 & $(0.735)$ \\
GDP60 & -0.0046 & $(2.23)$ & -0.025 \\
& $(-3.42)$ & -0.0057 & $(-1.77)$ \\
PRIM60 & 0.04 & $(-3.51)$ & 0.05 \\
& $(5.6)$ & & $(4.08)$ \\
GINI & & 0.0303 & $(2.31)$ \\
& -0.0376 & & -0.011 \\
& $(-1.833)$ & -0.0841 & $(-0.385)$ \\
\hline $\bar{R}^{2}$ & & $(-2.66)$ & 0.27 \\
\hline
\end{tabular}

Dependent variable: average per capita growth rate 1960-1985; Data sources: Barro/Wolf (89) [GR6085, GDP60, PRIM60]; Deininger/Squire (1996) [Gini, average value]. T-statistics in parentheses. Own Calculations. 
Figure 1

Impact of an increase in equality on the growth rate in regime RG3 with $\alpha=1$ and for different values of $\theta_{1}$.

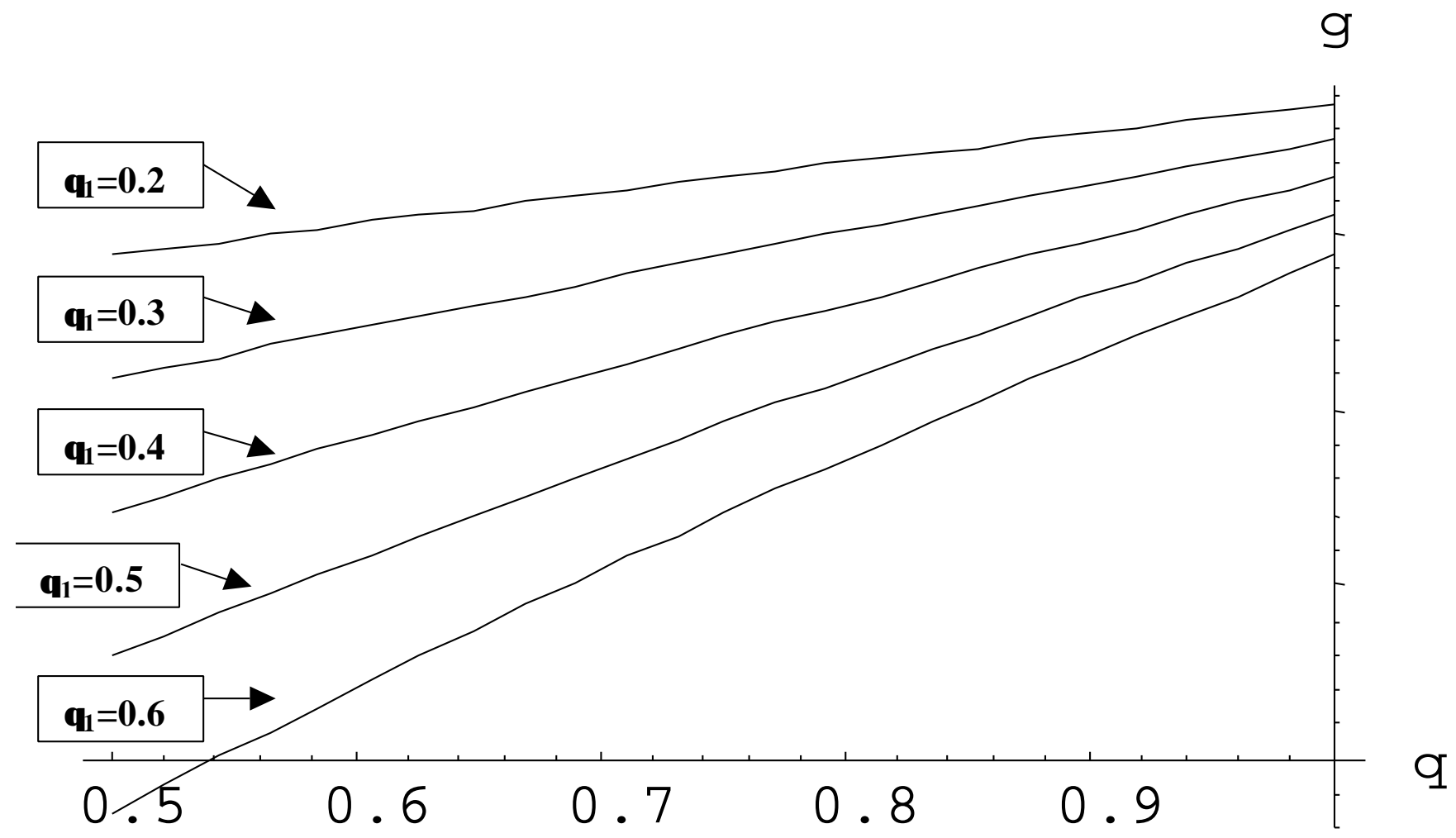

(In)equality is measured as: $\mathrm{q}=\frac{w^{p}}{\bar{w}}$. The growth rate is defined as in equation (2.6), where the following parametrization was used: $\alpha=1, \rho=1, \mathrm{p}=0.8, \bar{w}=100, \mathrm{~B}=5, \mathrm{k}=0.5$ and $\theta_{1}$ varies from 0.2 to 0.6 . 
Figure 2

Impact of an increase in equality on the growth rate in regimes RG1, RG2 and RG3 with $\alpha=1 / 2$ and $\theta_{2}=0$.

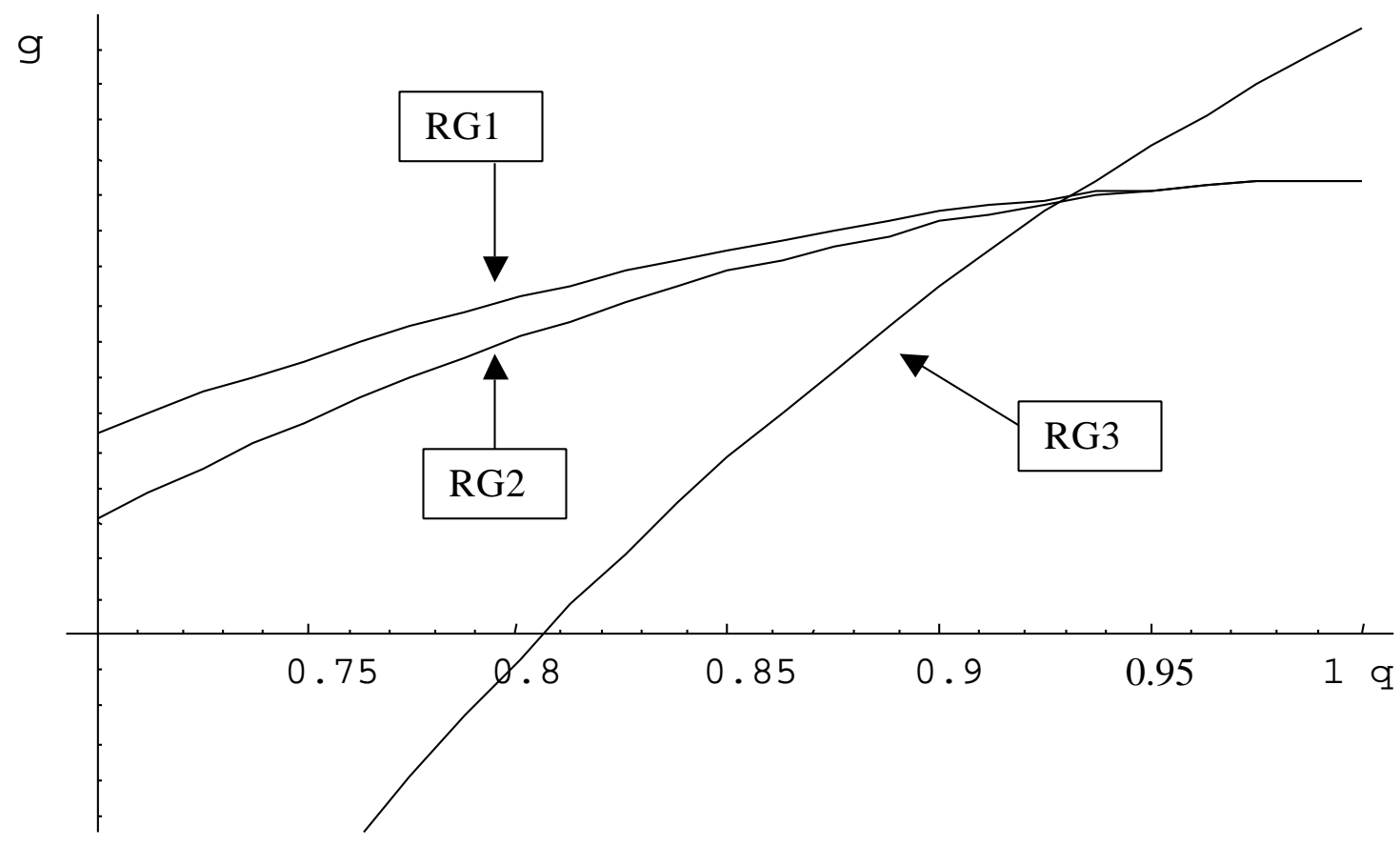

The parametrization is the same as in the example of Figure 1, only that now: $\alpha=1 / 2, \theta_{1}=0.2$ and $\theta_{2}=0$. 
Figure 3

Individualism and GDP

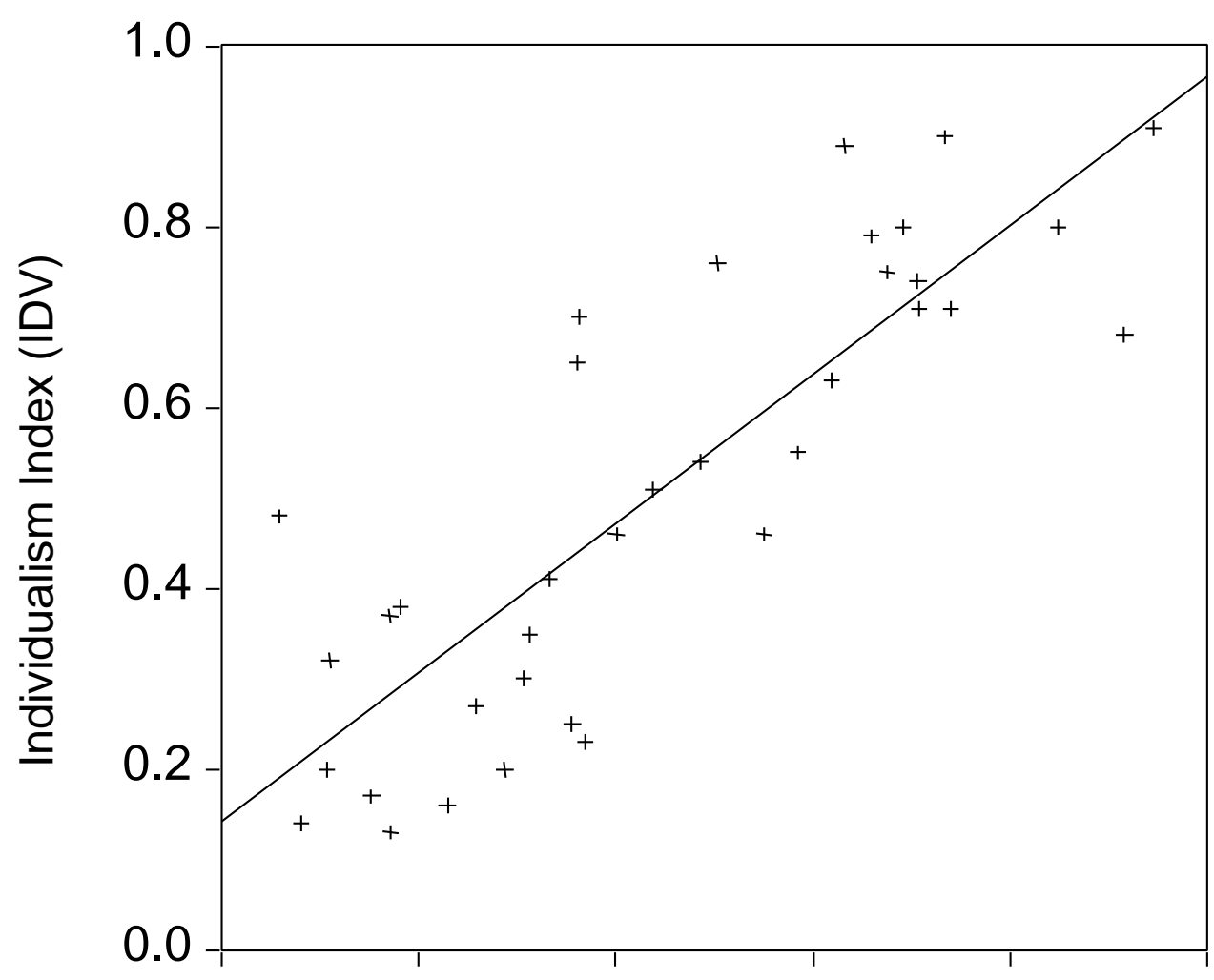

GDP per capita in 1970

Data Sources: GDP70 (Barro/Wolf, 1989); Individualism Index (IDV) (G. Hofstede,1982, p. 158). 